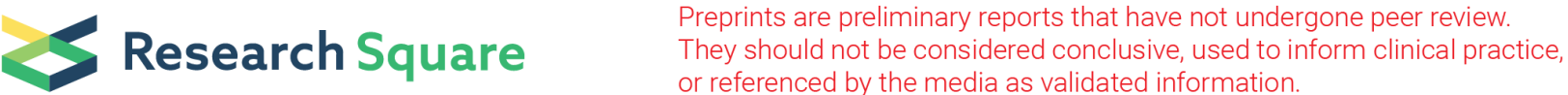

\section{The Linkage between Urban Built-up and Surface Water Quality: Inferences from the Parts of Karamana River Basin, Thiruvananthapuram, Kerala, India}

Mohammed-Aslam Mohammad AbdulKhader

Central University of Karnataka

Reshma Sisupalan Rema ( $\nabla$ reshmasr@cuk.ac.in )

Central University of Karnataka

\section{Research Article}

Keywords: Land use/land cover change, urbanization, water quality, Physico-chemical, biological parameter

Posted Date: November 1st, 2021

DOl: https://doi.org/10.21203/rs.3.rs-990203/v1

License: (c) (1) This work is licensed under a Creative Commons Attribution 4.0 International License. Read Full License 


\section{Abstract}

The linkage between the land use/land cover (LULC) pattern and water quality is an emerging topic in multidisciplinary research. The LULC changes affect water quality in many ways. Change in the land use/land cover, especially urbanization leads to water quality deterioration. This study mainly focuses on the water quality in parts of the river Karamana, which flows through the Thiruvananthapuram urban area. The water quality parameters of six selected sites within the urban area were obtained. Physicochemical and biological parameters of water quality were analysed for 2019 (pre-monsoon, monsoon, and post-monsoon). The water quality data obtained during the present study were used to characterize the built-up and other areas. Results have shown a distinct variation of parameters in the upstream region (less built-up) than that of the urban area (more built-up). The results have clearly demonstrated the indication of the effect of urbanization on water resources. The speedy development of urban built-up in Thiruvananthapuram city causing severe issues to the water regime in terms of its quality. The data shows that the water quality is poor in the pre-monsoon period in most of the areas. Though the worsening of water quality is limited to a few localized zones, the trend of the quality change is serious. It needs the attention and proper consideration of policy planners and decision-makers. Adequate effluent treatment facilities in the urban regions is the need of the hour to minimize pollution.

\section{Introduction}

Globalization helped in the rapid growth of the economy across the world and led to the movement of the people. Because of globalization, the other concept that came to its full swing is urbanization (Sadashivam \& Shahla, 2016). Urbanization is relatively a new phenomenon and is very closely related to the industrial revolution. Urbanization has a significant gradient in economic growth and social development (Franco et al.,2016). Urbanization is considered as the lifestyle transformation of the rural people with the increase of the urban built-up area. The historical evidence showed that it is concentrated in particular parts in several places and experience a global scale (Maurya, 2017). The conversion from traditional rural economies to modern industrial and service-based sectors has implications in the urbanization process (Jaysawal \& Saha, 2014). The gradual increase in the human population (Davis, 1965) has an effect in the change of both the spatial and demographic characteristics. The process of urbanization is measured mainly in terms of census statistics. It helps to discriminate against the residents of towns and cities (Smailes, 1975). Misra (1972) characterized urbanization using several parameters. The main consequence of urbanization is the spatial expansion of the cities into their intermediate surroundings to house the rising urban population (Mosammam et al., 2016). It will affect the elementary amenities and facilities in the urban environment like housing, sanitation, water supply, transport, etc. (Sadashivam \& Shahla, 2016). The cities grow based on the constant inflow of people. When this flow halts, then the urbanization move towards a standstill condition (Chaolin et al.,2012). The concern regarding the impact of the environment due to urbanization is found increasing in recent years (Brockerhoff, 1999). 
The definition of urban growth is the expansion of the urban area to the surrounding land. Urban development is to be dissected both spatially and temporally to discover the progressions in urban communities. It is a spatial process that necessitates the priority of systematic urban planning for developing cities. When large cities are congested with huge population, the smaller towns start to grow. Urban growth is faster in the larger cities than in the small towns. Various factors that support urban growth include globalization, living standard, land prices, transportation, jobs, social status, education, etc. (Bhagat and Soumya, 2009). Urban development has a substantial impact on health, environment and human development. Such changes have lot of significance in the economic development in nonindustrial nations like India. Unplanned urban development has adverse impacts on the environment.

Contamination of groundwater and surface resources occurs mainly through two ways: diffuse and point sources (Sudhakar and Mamatha, 2004). Pollutions from point sources mainly include the effluents from industries, untreated domestic sewage and waste from sewage treatment plants. The source of diffuse pollution is anthropogenic activities, like the usage of fertilizers and pesticides in agricultural fields, or natural geogenic contamination of groundwater sources. The water resource contamination is maximum in urban areas where large quantities of wastes are generated. Nowadays, the availability of proper sanitation facilities reduces and the direct discharge of wastes in surface water increases. But the seepage of waste into the groundwater from faulty pit latrines, or septic tanks affect the groundwater quality. The extensive usage of fertilizers and pesticides in the agricultural field cause serious health issues and contaminates groundwater through leaching or runoff (Sudhakar and Mamatha, 2004). Characterization of water quality is very essential for identifying its optimal uses (Lalitha and Mohammed-Aslam, 2018; Rizvi and Mohammed-Aslam, 2019; Mohammed-Aslam and Rizvi, 2020).

The spatial science and advanced methods offer considerable provisions for examining and monitoring the spatial changes in urban studies. The remote sensing and geographic information system (GIS) techniques are effectively used for mapping, monitoring and modelling urban growth. Remote sensing techniques are useful in land cover studies (Mohammed-Aslam et al., 2006; Mohammed-Aslam et al., 2010; Kumar and Kumar,2012; Mohammed-Aslam et al., 2020). Urban growth patterns and physical expressions on the landscape can be spotted, mapped and assessed through these techniques (Angel et al., 2005). These methods have effectively been executed to detect and model urban growth dynamics. Combining spatial information and logical strategies help the stake holders and decision-makers in their activities (Herold et al., 2003). Spatiotemporal analysis and modelling are helpful in the assessment of urban events. Urban classification based on the density of urban-settlements helps to identify the intensity of the urbanization process.

In India, the urban administrations are managed by the municipalities and corporations at local level. The participation of NGOs (non-governmental organizations) and private sectors in basic urban services benefit these local bodies. For example, such sectors can play an active role in the urban waste management. The operation of various activities by these local bodies have some constraints in their spatial jurisdictions. Many times, it may not be possible that several natural resource systems like groundwater reserves, watersheds or drainage basins in an urban zone may not exactly match with its 
administrative boundaries. There is less chance to accommodate such natural resources, if area is small (Whitney, 1990). Water quality issues are noticed in some urban settlements. People take long-term investments like tanks, hand pumps, or tube wells to get a sufficient amount of water. As per the World Health Organization guidelines, E. coli (a type of bacteria used to measure bacterial contamination) should be absent in a $100 \mathrm{ml}$ sample, which is considered as water of good quality. Less than ten coliforms in $100 \mathrm{ml}$ of sample water are regarded as "moderately" good quality. Waterborne diseases caused by fecal contamination result in major public health risks (Satapathy, 2014).

An attempt has been made in this study to find out the impact of urbanization in Thiruvananthapuram city covering the parts of Karamana river basin for the best urban water management.

\section{Urban Water System In Thiruvananthapuram City}

Thiruvananthapuram is the capital city of Kerala State in India. It is the largest and the most populous city in Kerala State. The center of Thiruvananthapuram city consists of a highly dense built-up area (Amrutha et al., 2016). The Thiruvananthapuram city is located within the Thiruvananthapuram District, which lies in the southern part of Kerala State. As per Census of India-2011 data the population of the district is 3,307,284 (Census of India, 2011). It is the second most populous district in the state and is the densest district with 1506 persons/sq.km (Sadashivam and Shahla, 2016).

The influence of population is considerably increasing in this Thiruvananthapuram city, which is being the seat of several administrative establishments along with other important institutions of government and private sectors. The population density is very high in the low land portion of the district, where the Thiruvananthapuram city is located (Table 1). The overall growth rate of population for the forty years until 2011, reveals that both the midland and lowland zones have almost close growth rates. The midland zone holds one-third of the population of the district. The boundary of the corporation comes under the lowland zone (Charutha and Anilkumar, 2015).

Table:1 Population growth rate in percentage (Charutha and Anilkumar, 2015)

\begin{tabular}{|llllll|}
\hline Physiographic Division & \multicolumn{5}{c|}{ Population in Percentage } \\
\cline { 2 - 6 } & $\mathbf{1 9 7 1}$ & $\mathbf{1 9 8 1}$ & $\mathbf{1 9 9 1}$ & $\mathbf{2 0 0 1}$ & $\mathbf{2 0 1 1}$ \\
\hline Low land & 54.82 & 55.42 & 54.85 & 51.89 & 55.25 \\
\hline Mid land & 38.58 & 39.21 & 39.94 & 43.09 & 4.05 \\
\hline Highland & 6.58 & 5.35 & 5.20 & 5.01 & 4.69 \\
\hline
\end{tabular}

Thiruvananthapuram city has a better drinking water supply among all capital cities in India (Srikumar and Harilal, 2017). The pipe water supply project, named Wellington Water Works covering an area of about $30 \mathrm{~km}^{2}$ and serving a population of 1.35 lakh, was started in 1933 in Thiruvananthapuram city 
(Srikumar and Harilal, 2017). The water quality checking points were arranged in various points, and this scheme was considered as one of the best schemes in India in 1933. In order to meet the present-day requirement, the Thiruvananthapuram city is mainly dependent on the Aruvikkara reservoir, which has a storage capacity of about 2 million cubic meters. This reservoir is located in the Karamana river basin. The water supply of the city is managed by Kerala Water Authority (KWA). However, the residents of some of rural areas face water scarcity due to lack of water resources or unavailability of pipe water. In some places like Vizhinjam and the coastal track of the Kovalam coast people have to purchase drinking water for their use (Srikumar and Harilal, 2017).

\section{Study Area}

The study area includes the parts of Karamana river basin, which is situated between North latitudes $8^{\circ}$ $05^{\prime}$ and $8^{\circ} 45^{\prime}$ and east longitudes $76^{\circ} 45^{\prime}$ and $77^{\circ} 15^{\prime}$. The focus of the present study was limited to mainly on the built-up area. The catchment of the Karamana river is having an area of about $702 \mathrm{~km}^{2}$, and the total length of the main channel is about $68 \mathrm{~km}$. Karamana river is one of the most significant river flows through Thiruvananthapuram, a highly urbanized capital city of Kerala (Sreeja, 2017). This river originates from the Western Ghats and confluences into the Arabian sea. The origin of river is at Chemmunji Mottai, a peak in the Sahyadri hills, at an altitude of about $1717 \mathrm{~m}$ amsl (above mean sea level). Soil types of the study area include forest loam, lateritic soil, riverine alluvium and coastal alluvium. The annual maximum and minimum temperatures of the area are $31^{\circ} \mathrm{C}$ and $24^{\circ} \mathrm{C}$, respectively. The study area receives an average annual rainfall of about $2600 \mathrm{~mm}$ (Sujitha et al., 2012). The district remains highly humid (79\%) throughout the year. The total population in the study area is about 16.2 lakhs (Sreeja, 2017).

\section{Data And Methodology}

To identify the river water quality parameters, the data maintained by the State Water Monitoring Programme (SWMP) of Kerala State Pollution Control Board (KSPCB) were taken for the year 2019 (data accessed from keralapcb.nic.in). Water quality data were analysed for the stations at Peppara dam (station 1), Aruvikkara (station 2), Mangattukadavu (station 3), Pallathukadavu (station 4), Thiruvallom (station 5), and Moonnattumukk (station 6). The parameters considered for the study are (Table 2) temperature, $\mathrm{pH}$, turbidity, biological oxygen demand (BOD), free ammonia, electric conductivity (EC), dissolved oxygen (DO), total hardness, alkalinity, calcium, magnesium, sodium, potassium, boron, chloride, sodium adsorption ratio (SAR), total coliform (TC), fecal coliform (FC), ammonia nitrogen $\left(\mathrm{NH}_{3}{ }^{-}\right.$ $\mathrm{N})$, nitrate, phosphate and sulphate. The data compiled by the River Rejuvenation Committee (RRC) of Kerala State Pollution Control Board in a monthly format. In the present study, these monthly data was classified into seasonal basis as pre-monsoon (February, March, April, May), monsoon (June, July, August, September) and post-monsoon (October, November, December, January). The mean values for all parameters were calculated based on these seasons (Table 2) to represent the quality range in the map. The designated best use of water quality criteria compiled by Central Pollution Control Board (CPCB) has been used in this study to characterise the water quality 
(https://cpcb.nic.in/wqm/Designated_Best_Use_Water_Quality_Criteria.pdf). The river water quality has been characterised based on the criteria prescribed by CPCB (Table 3 ).

Optical satellite imagery from Sentinel 2 (10m resolution) was used for the computation of Normalized Difference Built-up Index (NDBI) classification to identify the built-up pattern of the study area. The Sentinel-2 data is a global multispectral data having 13 bands in visible, near-infrared, and short-wave infrared spectrum. The radiometric resolution of SENTINEL-2 (https:// earthexplorer.usgs.gov.in) is 12-bit. The classification of the Sentinel data of February 2019 gives a detailed representation of urban zones and non-urban zones of the study area. The equation to derive NDBI from Sentinel 2 is (Eq. 1)

$\mathrm{NDBI}=(\mathrm{SWIR}-\mathrm{NIR}) /(\mathrm{SWIR}+\mathrm{NIR})(1)$

Where, band 8 is NIR and band 12 for SWIR in Sentinal-2 data.

Table: 2 Water quality parameters of Karamana river

Table 3: The classification of the samples in the study area and designated best use water quality criteria as per $\mathrm{CPCB}$ 


\begin{tabular}{|c|c|c|c|c|c|}
\hline Temperature & Location & Premonsoon & Monsoon & Postmonsoon & $\begin{array}{l}\text { Annual } \\
\text { Avg }\end{array}$ \\
\hline (- ) & Peppara & 32.25 & 32.4 & 28.8 & 31.150 \\
\hline & Aruvikkara & 33.25 & 31.78 & 30 & 31.677 \\
\hline & Mangattukadavu & 32.78 & 32.58 & 29.83 & 31.730 \\
\hline & Pallathukadavu & 32.45 & 32.35 & 30.175 & 31.658 \\
\hline & Thiruvallom & 33 & 31.25 & 29.75 & 31.333 \\
\hline & Moonnattumukk & 33.25 & 31.25 & 30 & 31.500 \\
\hline $\mathrm{pH}$ & Location & Premonsoon & Monsoon & Postmonsoon & $\begin{array}{l}\text { Annual } \\
\text { avg }\end{array}$ \\
\hline & Peppara & 6.48 & 6.61 & 6.89 & 6.660 \\
\hline & Aruvikkara & 6.25 & 6.65 & 6.83 & 6.577 \\
\hline & Mangattukadavu & 6.35 & 6.47 & 6.62 & 6.480 \\
\hline & Pallathukadavu & 6.8 & 6.74 & 6.82 & 6.787 \\
\hline & Thiruvallom & 6.65 & 6.83 & 5.88 & 6.453 \\
\hline & Moonnattumukk & 6.65 & 6.85 & 6.58 & 6.693 \\
\hline Turbidity & Location & Premonsoon & Monsoon & Postmonsoon & $\begin{array}{l}\text { Annual } \\
\text { avg }\end{array}$ \\
\hline & Peppara & 0.45 & 0.6 & 1.98 & 1.010 \\
\hline & Aruvikkara & 2.98 & 1.3 & 3.83 & 2.703 \\
\hline & Mangattukadavu & 0.2 & 3.7 & 3.2 & 2.367 \\
\hline & Pallathukadavu & 6.6 & 4.43 & 7.08 & 6.037 \\
\hline & Thiruvallom & 5.68 & 3.73 & 5.58 & 4.997 \\
\hline & Moonnattumukk & 29 & 7.63 & 3 & 13.210 \\
\hline EC & Location & Premonsoon & Monsoon & Postmonsoon & $\begin{array}{l}\text { Annual } \\
\text { avg }\end{array}$ \\
\hline & Peppara & 69.38 & 46.5 & 76.25 & 64.043 \\
\hline & Aruvikkara & 109.25 & 114.5 & 94.75 & 106.167 \\
\hline & Mangattukadavu & 80.25 & 56 & 92 & 76.083 \\
\hline & Pallathukadavu & 99.5 & 126.25 & 83.5 & 103.083 \\
\hline & Thiruvallom & 311.75 & 388.25 & 265 & 321.667 \\
\hline
\end{tabular}




\begin{tabular}{|c|c|c|c|c|c|}
\hline & Moonnattumukk & 605 & 615 & 559.5 & 593.167 \\
\hline \multirow{7}{*}{$\begin{array}{l}\text { DO } \\
\text { (mg/l) }\end{array}$} & Location & Premonsoon & Monsoon & Postmonsoon & $\begin{array}{l}\text { Annual } \\
\text { avg }\end{array}$ \\
\hline & Peppara & 5.83 & 5.7 & 6.65 & 6.1 \\
\hline & Aruvikkara & 6.1 & 6.28 & 6.85 & 6.4 \\
\hline & Mangattukadavu & 5.6 & 5.63 & 6.2 & 5.8 \\
\hline & Pallathukadavu & 4.6 & 1.78 & 4.43 & 3.6 \\
\hline & Thiruvallom & 1.73 & 1.1 & 0.6 & 1.1 \\
\hline & Moonnattumukk & 0.85 & 1.03 & 0.43 & 0.8 \\
\hline \multirow{7}{*}{$\begin{array}{l}\text { BOD } \\
(\mathrm{mg} / \mathrm{l})\end{array}$} & Location & Premonsoon & Monsoon & Postmonsoon & $\begin{array}{l}\text { Annual } \\
\text { avg }\end{array}$ \\
\hline & Peppara & 2.48 & 2.65 & 2.35 & 2.493 \\
\hline & Aruvikkara & 2.6 & 3.23 & 2.13 & 2.653 \\
\hline & Mangattukadavu & 2.4 & 2.55 & 3.73 & 2.893 \\
\hline & Pallathukadavu & 4.08 & 1.8 & 2.4 & 2.760 \\
\hline & Thiruvallom & 7.8 & 4.83 & 11.58 & 8.070 \\
\hline & Moonnattumukk & 6.93 & 5.28 & 6.73 & 6.313 \\
\hline \multirow[t]{7}{*}{ Free Ammonia } & Location & Premonsoon & Monsoon & Postmonsoon & $\begin{array}{l}\text { Annual } \\
\text { avg }\end{array}$ \\
\hline & Peppara & BDL & $\mathrm{BDL}$ & BDL & BDL \\
\hline & Aruvikkara & $\mathrm{BDL}$ & $\mathrm{BDL}$ & $\mathrm{BDL}$ & $\mathrm{BDL}$ \\
\hline & Mangattukadavu & $\mathrm{BDL}$ & $\mathrm{BDL}$ & $\mathrm{BDL}$ & $\mathrm{BDL}$ \\
\hline & Pallathukadavu & $\mathrm{BDL}$ & $\mathrm{BDL}$ & $\mathrm{BDL}$ & $\mathrm{BDL}$ \\
\hline & Thiruvallom & $\mathrm{BDL}$ & $\mathrm{BDL}$ & $\mathrm{BDL}$ & $\mathrm{BDL}$ \\
\hline & Moonnattumukk & $\mathrm{BDL}$ & $\mathrm{BDL}$ & $\mathrm{BDL}$ & $\mathrm{BDL}$ \\
\hline \multirow{5}{*}{$\begin{array}{l}\text { Chloride } \\
(\mathrm{mg} / \mathrm{l})\end{array}$} & Location & Premonsoon & Monsoon & Postmonsoon & $\begin{array}{l}\text { Annual } \\
\text { avg }\end{array}$ \\
\hline & Peppara & 46.5 & 22 & 29 & 32.500 \\
\hline & Aruvikkara & 17.25 & 30 & 18.25 & 21.833 \\
\hline & Mangattukadavu & 41.5 & 36.5 & 45 & 41.000 \\
\hline & Pallathukadavu & 276 & 347 & 87.5 & 236.833 \\
\hline
\end{tabular}




\begin{tabular}{|c|c|c|c|c|c|}
\hline & Thiruvallom & 72 & 73.75 & 56.5 & 67.417 \\
\hline & Moonnattumukk & 117.25 & 106 & 101 & 108.083 \\
\hline \multirow[t]{7}{*}{$\begin{array}{l}\text { Total } \\
\text { alkalinity (mg/l) }\end{array}$} & Location & Premonsoon & Monsoon & Postmonsoon & $\begin{array}{l}\text { Annual } \\
\text { avg }\end{array}$ \\
\hline & Peppara & 44 & 36.75 & 46.75 & 42.500 \\
\hline & Aruvikkara & 24 & 28 & 21.5 & 24.500 \\
\hline & Mangattukadavu & 54.5 & 62 & 65.75 & 60.750 \\
\hline & Pallathukadavu & 170.25 & 121.5 & 145 & 145.583 \\
\hline & Thiruvallom & 25.73 & 58.88 & 43.5 & 42.703 \\
\hline & Moonnattumukk & 55 & 78 & 81.5 & 71.500 \\
\hline \multirow[t]{7}{*}{$\begin{array}{l}\text { Total } \\
\text { hardness }(\mathrm{mg} / \mathrm{l})\end{array}$} & Location & Premonsoon & Monsoon & Postmonsoon & $\begin{array}{l}\text { Annual } \\
\text { avg }\end{array}$ \\
\hline & Peppara & 30.25 & 5.75 & 16.75 & 17.583 \\
\hline & Aruvikkara & 36.5 & 33 & 28.25 & 32.583 \\
\hline & Mangattukadavu & 50.25 & 26.5 & 32.5 & 36.417 \\
\hline & Pallathukadavu & 196.5 & 113.5 & 70 & 126.667 \\
\hline & Thiruvallom & 100 & 108.75 & 76.25 & 95.000 \\
\hline & Moonnattumukk & 179.25 & 100.5 & 141 & 140.250 \\
\hline \multirow[t]{7}{*}{ Calcium (mg/l) } & Location & Premonsoon & Monsoon & Postmonsoon & $\begin{array}{l}\text { Annual } \\
\text { avg }\end{array}$ \\
\hline & Peppara & 20.5 & 3.25 & 11.5 & 11.750 \\
\hline & Aruvikkara & 22.75 & 24.75 & 20.25 & 22.583 \\
\hline & Mangattukadavu & 33.75 & 18.5 & 20.5 & 24.250 \\
\hline & Pallathukadavu & 109.75 & 86 & 46 & 80.583 \\
\hline & Thiruvallom & 55.75 & 69.75 & 50.75 & 58.750 \\
\hline & Moonnattumukk & 116 & 78.5 & 102.25 & 98.917 \\
\hline \multirow[t]{4}{*}{ Magnesium (mg/l) } & Location & Premonsoon & Monsoon & Postmonsoon & $\begin{array}{l}\text { Annual } \\
\text { avg }\end{array}$ \\
\hline & Peppara & 9.75 & 2.5 & 5.25 & 5.833 \\
\hline & Aruvikkara & 13.75 & 8.25 & 8 & 10.000 \\
\hline & Mangattukadavu & 16.5 & 8 & 12 & 12.167 \\
\hline
\end{tabular}




\begin{tabular}{|c|c|c|c|c|c|}
\hline & Pallathukadavu & 86.75 & 27.5 & 24 & 46.083 \\
\hline & Thiruvallom & 44.25 & 39 & 25.5 & 36.250 \\
\hline & Moonnattumukk & 63.25 & 22 & 39.25 & 41.500 \\
\hline \multirow[t]{7}{*}{ Sodium (mg/l) } & Location & Premonsoon & Monsoon & Postmonsoon & $\begin{array}{l}\text { Annual } \\
\text { avg }\end{array}$ \\
\hline & Peppara & 0.88 & 0.95 & 6.28 & 2.703 \\
\hline & Aruvikkara & 7.9 & 11.03 & 5.15 & 8.027 \\
\hline & Mangattukadavu & 4.3 & 8.6 & 10.13 & 7.677 \\
\hline & Pallathukadavu & 20.03 & 73.63 & 9.1 & 34.253 \\
\hline & Thiruvallom & 23.63 & 29.25 & 18.63 & 23.837 \\
\hline & Moonnattumukk & 37.38 & 57.13 & 45.48 & 46.663 \\
\hline \multirow[t]{7}{*}{ Potassium (mg/l) } & Location & Premonsoon & Monsoon & Postmonsoon & $\begin{array}{l}\text { Annual } \\
\text { avg }\end{array}$ \\
\hline & Peppara & 1.25 & 1.28 & 1.78 & 1.437 \\
\hline & Aruvikkara & 1.15 & 4.18 & 1.6 & 2.310 \\
\hline & Mangattukadavu & 2.75 & 2.45 & 4.25 & 3.150 \\
\hline & Pallathukadavu & 4.075 & 7.76 & 10.3 & 7.378 \\
\hline & Thiruvallom & 13.6 & 6.35 & 5.6 & 8.517 \\
\hline & Moonnattumukk & 9.83 & 30 & 9.45 & 16.427 \\
\hline \multirow[t]{7}{*}{ Boron(mg/l) } & Location & Premonsoon & Monsoon & Postmonsoon & $\begin{array}{l}\text { Annual } \\
\text { avg }\end{array}$ \\
\hline & Peppara & $\mathrm{BDL}$ & $\mathrm{BDL}$ & $\mathrm{BDL}$ & $\mathrm{BDL}$ \\
\hline & Aruvikkara & $\mathrm{BDL}$ & $\mathrm{BDL}$ & $\mathrm{BDL}$ & $\mathrm{BDL}$ \\
\hline & Mangattukadavu & $\mathrm{BDL}$ & $\mathrm{BDL}$ & $\mathrm{BDL}$ & $\mathrm{BDL}$ \\
\hline & Pallathukadavu & $\mathrm{BDL}$ & $\mathrm{BDL}$ & $\mathrm{BDL}$ & $\mathrm{BDL}$ \\
\hline & Thiruvallom & $\mathrm{BDL}$ & $\mathrm{BDL}$ & $\mathrm{BDL}$ & $\mathrm{BDL}$ \\
\hline & Moonnattumukk & $\mathrm{BDL}$ & $\mathrm{BDL}$ & $\mathrm{BDL}$ & $\mathrm{BDL}$ \\
\hline \multirow[t]{3}{*}{ SAR } & Location & Premonsoon & Monsoon & Postmonsoon & $\begin{array}{l}\text { Annual } \\
\text { avg }\end{array}$ \\
\hline & Peppara & 0 & 0.07 & 0.53 & 0.200 \\
\hline & Aruvikkara & 0 & 0.3 & 0.21 & 0.170 \\
\hline
\end{tabular}




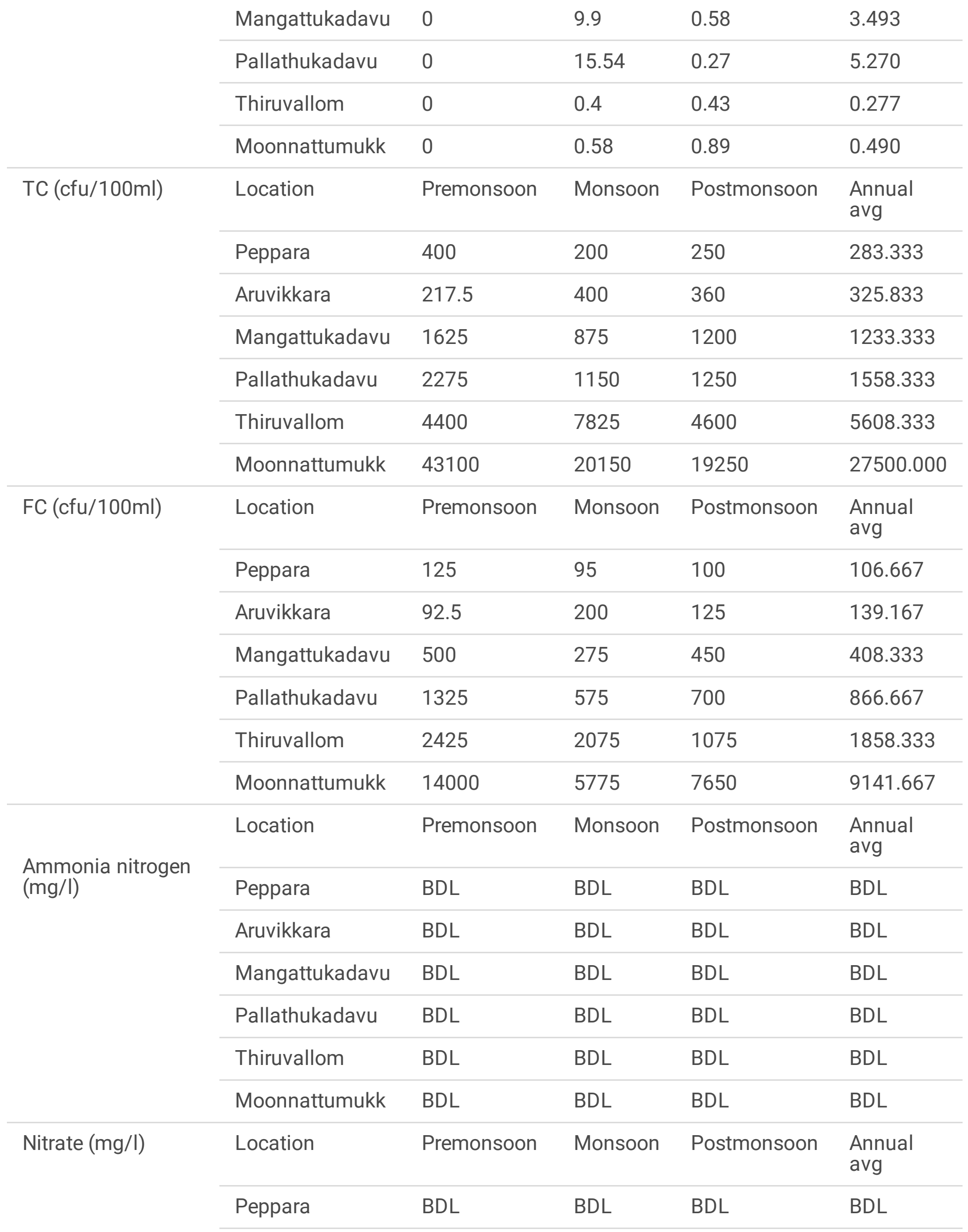




\begin{tabular}{|c|c|c|c|c|c|}
\hline & Aruvikkara & $\mathrm{BDL}$ & $\mathrm{BDL}$ & $\mathrm{BDL}$ & $\mathrm{BDL}$ \\
\hline & Mangattukadavu & $\mathrm{BDL}$ & $\mathrm{BDL}$ & $\mathrm{BDL}$ & $\mathrm{BDL}$ \\
\hline & Pallathukadavu & $\mathrm{BDL}$ & $\mathrm{BDL}$ & $\mathrm{BDL}$ & $\mathrm{BDL}$ \\
\hline & Thiruvallom & $\mathrm{BDL}$ & $\mathrm{BDL}$ & $\mathrm{BDL}$ & $\mathrm{BDL}$ \\
\hline & Moonnattumukk & 0.85 & 1.325 & 1.25 & 1.1416 \\
\hline & Location & Premonsoon & Monsoon & Postmonsoon & $\begin{array}{l}\text { Annual } \\
\text { avg }\end{array}$ \\
\hline & Peppara & $\mathrm{BDL}$ & BDL & $\mathrm{BDL}$ & $\mathrm{BDL}$ \\
\hline & Aruvikkara & $\mathrm{BDL}$ & BDL & $\mathrm{BDL}$ & $\mathrm{BDL}$ \\
\hline Phosphate (mg/l) & Mangattukadavu & $\mathrm{BDL}$ & BDL & $\mathrm{BDL}$ & $\mathrm{BDL}$ \\
\hline & Pallathukadavu & $\mathrm{BDL}$ & BDL & $\mathrm{BDL}$ & $\mathrm{BDL}$ \\
\hline & Thiruvallom & $\mathrm{BDL}$ & BDL & $\mathrm{BDL}$ & $\mathrm{BDL}$ \\
\hline & Moonnattumukk & $\mathrm{BDL}$ & $\mathrm{BDL}$ & $\mathrm{BDL}$ & $\mathrm{BDL}$ \\
\hline & Location & Premonsoon & Monsoon & Postmonsoon & $\begin{array}{l}\text { Annual } \\
\text { avg }\end{array}$ \\
\hline & Peppara & $\mathrm{BDL}$ & BDL & $\mathrm{BDL}$ & $\mathrm{BDL}$ \\
\hline Sulphate (mg/l) & Aruvikkara & $\mathrm{BDL}$ & BDL & $\mathrm{BDL}$ & BDL \\
\hline & Mangattukadavu & $\mathrm{BDL}$ & BDL & $\mathrm{BDL}$ & $\mathrm{BDL}$ \\
\hline & Pallathukadavu & $\mathrm{BDL}$ & BDL & $\mathrm{BDL}$ & $\mathrm{BDL}$ \\
\hline & Thiruvallom & 0.85 & 0.625 & 0.975 & 0.825 \\
\hline & Moonnattumukk & 32 & 33.75 & 26.75 & 30.83 \\
\hline
\end{tabular}




\begin{tabular}{|c|c|c|c|}
\hline \multicolumn{3}{|c|}{ Designated best use water quality criteria as per CPCB } & \multirow{2}{*}{$\begin{array}{l}\text { Water quality class of sampling } \\
\text { locations }\end{array}$} \\
\hline Designated-Best-Use & $\begin{array}{l}\text { Class } \\
\text { of } \\
\text { water }\end{array}$ & Criteria & \\
\hline \multirow{4}{*}{$\begin{array}{l}\text { Drinking-Water Source } \\
\text { without conventional } \\
\text { treatment but after } \\
\text { disinfection }\end{array}$} & A & $\begin{array}{l}\text { Total Coliforms } \\
\text { Organism MPN/ } 100 \mathrm{ml} \\
\text { shall be } 50 \text { or less; }\end{array}$ & \multirow[t]{4}{*}{$\begin{array}{l}\text { None of the stations listed as } \\
\text { Class A }\end{array}$} \\
\hline & & $\begin{array}{l}\mathrm{pH} \text { between } 6.5 \text { and } \\
8.5 \text {; }\end{array}$ & \\
\hline & & $\begin{array}{l}\text { Dissolved Oxygen } \\
6 \mathrm{mg} / \mathrm{l} \text { or more; }\end{array}$ & \\
\hline & & $\begin{array}{l}\text { Biochemical Oxygen } \\
\text { Demand } 5 \text { days } 20 \mathrm{C} \\
2 \mathrm{mg} / \mathrm{l} \text { or less; }\end{array}$ & \\
\hline \multirow[t]{4}{*}{ Outdoor bathing (Organised) } & B & $\begin{array}{l}\text { Total Coliforms } \\
\text { Organism MPN/ } 100 \mathrm{ml} \\
\text { shall be } 500 \text { or less; }\end{array}$ & \multirow[t]{4}{*}{$\begin{array}{l}\text { Peppara and Aruvikkara stations } \\
\text { are classified as Class B }\end{array}$} \\
\hline & & $\begin{array}{l}\text { pH between } 6.5 \text { and } \\
8.5 \text {; }\end{array}$ & \\
\hline & & $\begin{array}{l}\text { Dissolved Oxygen } \\
5 \mathrm{mg} / \mathrm{l} \text { or more; }\end{array}$ & \\
\hline & & $\begin{array}{l}\text { Biochemical Oxygen } \\
\text { Demand } 5 \text { days } 20 \mathrm{C} \\
3 \mathrm{mg} / \mathrm{l} \text { or less }\end{array}$ & \\
\hline \multirow[t]{4}{*}{$\begin{array}{l}\text { Drinking water source after } \\
\text { conventional treatment and } \\
\text { disinfection }\end{array}$} & $\mathrm{C}$ & $\begin{array}{l}\text { Total Coliforms } \\
\text { Organism MPN/ } 100 \mathrm{ml} \\
\text { shall be } 5000 \text { or less; }\end{array}$ & \multirow[t]{4}{*}{$\begin{array}{l}\text { Mangattukadavu is classified as } \\
\text { Class C }\end{array}$} \\
\hline & & $\mathrm{pH}$ between 6 to 9; & \\
\hline & & $\begin{array}{l}\text { Dissolved Oxygen } \\
4 \mathrm{mg} / \mathrm{l} \text { or more; }\end{array}$ & \\
\hline & & $\begin{array}{l}\text { Biochemical Oxygen } \\
\text { Demand } 5 \text { days 20C } \\
\text { 3mg/l or less; }\end{array}$ & \\
\hline \multirow{3}{*}{$\begin{array}{l}\text { Propagation of Wildlife and } \\
\text { Fisheries }\end{array}$} & $\mathrm{D}$ & $\mathrm{pH}$ between 6.5 to 8.5 & \multirow{3}{*}{$\begin{array}{l}\text { Pallathukadavu during pre- } \\
\text { monsoon and post monsoon } \\
\text { seasons classified as Class D }\end{array}$} \\
\hline & & $\begin{array}{l}\text { Dissolved Oxygen } \\
4 \mathrm{mg} / \mathrm{l} \text { or more; }\end{array}$ & \\
\hline & & $\begin{array}{l}\text { Free Ammonia (as } \mathrm{N} \text { ) } \\
1.2 \mathrm{mg} / \mathrm{l} \text { or less; }\end{array}$ & \\
\hline \multirow{2}{*}{$\begin{array}{l}\text { Irrigation, Industrial Cooling, } \\
\text { Controlled Waste disposal }\end{array}$} & E & pH between 6.0 to 8.5 & \multirow{2}{*}{$\begin{array}{l}\text { Thiruvallom and } \\
\text { Moonnattumukk stations are } \\
\text { classified as Class E }\end{array}$} \\
\hline & & $\begin{array}{l}\text { Electrical Conductivity } \\
\text { at } 25 \mathrm{C} \text { micro }\end{array}$ & \\
\hline
\end{tabular}

Page 13/24 
The parameters like temperature, salinity, EC, pH, DO, color, odor are the main factors in determining the river water quality. The dissolved oxygen level determines the presence of aquatic plants and animals. Most of the rivers in urban areas have significantly less DO levels having strong influence on biological oxygen demand. The BOD level increases due to the dumping of sewage waste into the surface water. This results in the decomposition of the organic bacteria. The $\mathrm{pH}$ affects both the chemical and biological processes. Most of the aquatic organisms can only survive in a particular range of $\mathrm{pH}$ values. Conductivity values represent the presence of mineral acids, salts, or similar contaminants present in the water. The rise in the dissolved solids increases water density and thereby affecting the life of aquatic organisms. The direct discharge of industrial waste increases the conductivity of water. The sources of total suspended solids (TSS) include a wide variety of materials, such as silt, waste from industries, decaying plant and animal waste and sewage. The TSS (>500) blocks sunlight which affects the life of the bottom-dwelling organisms. It can also cause an increase in surface water temperature by absorbing heat from sunlight, thereby leading to depletion in dissolved oxygen (Chang, 2005). The other important parameters like nitrate and phosphate reach the water from the fertilizers and pesticides used in the agricultural fields. The process of leaching in soil results in the concentration of chemical constituents in groundwater.

\section{Results And Discussion}

Sixteen parameters were considered to analyze the water quality of the Karamana river from 6 stations all over the river basin. The salient observations found in the study area are discussed as follows:

The temperature is an essential factor for analysing the water quality of river samples. The temperature changes in different seasons can be easily measured and differentiated. The highest temperature in the pre-monsoon period and lowest in the post-monsoon were observed. The highest value was $33.25^{\circ} \mathrm{C}$ is in Aruvikkara and Moonnattumukk (Fig. 4). The lowest temperature value was $28.8^{\circ} \mathrm{C}$ is in the source region at Peppara dam (Table 2). The $\mathrm{pH}$ level of the water measures the acidic and basic nature of water. $\mathrm{pH}$ value of 7 means neutral, less than 7 means acidic and greater than 7 is alkaline in nature (Sujitha et al.,2012). The pH regulating ions are the carbonates (APHA, 1995). The limit of 6.5 is the tolerable level of the $\mathrm{pH}$ of river water (Krishnakumar, 1998). Except for Thiruvallom ( $\mathrm{pH}$ of 5.8) in the post-monsoon season (Table 2), the pH of all other stations was within the tolerable limit (Fig. 2). The conductivity is the water's ability to conduct electric currents. The dissolved salts, mainly of $\mathrm{NaCl}$ and $\mathrm{KCl}$ influence the conductance rate. The conductivity range of the samples from the study area was from $69.38 \mu / \mathrm{s}$ to $605 \mu / \mathrm{s}$ and from $46.5 \mu / \mathrm{s}$ to $615 \mu / \mathrm{s}$, and $76.25 \mu / \mathrm{s}$ to $559.6 \mu / \mathrm{s}$ respectively, during pre- 
monsoon, monsoon and post-monsoon seasons (Table 2). The slightly high conductivity was shown in the Moonnattumukk station (Fig. 3) in all seasons; which may be due to the seawater intrusion as the station is near the coastal zone. Total alkalinity is defined as measuring the total amount of alkaline substances dissolved in the water. The alkalinity from natural sources is not considered as hazardous. The total alkalinity value ranges from $24 \mathrm{mg} / \mathrm{l}$ (Station 2) to $170.25 \mathrm{mg} / \mathrm{l}$ (Station 4) in pre-monsoon, 28 $\mathrm{mg} / \mathrm{l}$ (Station 2) to $121.5 \mathrm{mg} / \mathrm{l}$ (Station 4) in monsoon and $21.5 \mathrm{mg} / \mathrm{l}$ (Station 2) to $145 \mathrm{mg} / \mathrm{l}$ (Station 4 ) in post-monsoon. Turbidity is defined as the measure of the relative clarity of a liquid. It is an optical characteristic of water. Turbidity is measured in Nephelometric Turbidity Units (NTU). Except for Moonnattumukk (Station 6) in pre-monsoon, all other stations have significantly less turbidity rate in all seasons. The high turbidity may be due to the growth of algae. The algae growth is typical in many parts of the river during the pre-monsoon time. Phosphorus from different sources can cause algal growth resulting in increased turbidity. The sources include discharges of wastewater treatment plants and nutrient runoff from cropland. Organic matter from sewage discharges can contribute to turbidity (Steven, 2008).

Chloride increases the electrical conductivity of water and thus increases its corrosivity. The chlorides reach the surface water through the wastewater from industries. Rocks contain chlorides can also contribute its concentration in groundwater. Only station 4 (Pallathukadavu) showed the high chloride content in pre-monsoon and monsoon seasons $(276 \mathrm{mg} / \mathrm{l}$ and $347 \mathrm{mg} / \mathrm{l})$ (Table 2). High chloride concentration in monsoon may be due to the sewage runoff near the station. The highest value of calcium in Moonnattumukk (Station 6) was $102.25 \mathrm{mg} / \mathrm{l}$ in post-monsoon season and the lowest was in Peppara $3.25 \mathrm{mg} / \mathrm{l}$ in monsoon season. Only at Moonnattumukk in pre-monsoon and post-monsoon the value exceeds $100 \mathrm{mg} / \mathrm{l}$. In all the other stations the values were below 80 (Table 2) except at Pallathukadavu during pre-monsoon. Except at Station 4 with a value of $86 \mathrm{mg} / \mathrm{l}$ (Pallathukadavu) and station 6 with value of $63 \mathrm{mg} / \mathrm{l}$ (Moonnattumukk) in pre-monsoon time, and all the other samples were with less magnesium concentration in all the seasons (Table 2). The highest value of sodium was in Pallathukadavu (station 4) with the value $73.63 \mathrm{mg} / \mathrm{l}$ in the monsoon season and the lowest in the Peppara dam $(0.88 \mathrm{mg} / \mathrm{l})$. The sodium level in Peppara dam and Aruvikkara is less compared with the other sampling stations (Table 2). The potassium level in the Peppara dam water sample was comparatively less like calcium and sodium. The highest level of potassium was in Thiruvallom (13.6 $\mathrm{mg} / \mathrm{l})$ in pre-monsoon season and the lowest was in Aruvikkara $(1.15 \mathrm{mg} / \mathrm{l})$ pre-monsoon season (Table 2). Boron was not recorded in all the stations.

The dissolved oxygen is the indicator of the health of aquatic organisms. The permissible limit of DO in river water used as a drinking water source after conventional treatment and disinfection is $>4 \mathrm{mg} / \mathrm{l}$ (Table 3). Except for stations 5 and 6 (Thiruvallom and Moonnattumukk), all other stations have relatively higher DO content in all (Fig:1). The highest DO content was in Aruvikkara (Station 2) water sample. The high DO content in most of the areas may be due to the open exposure and the dissolution of the high amount of atmospheric oxygen in the water. The two stations which recorded the low DO may be due to the higher BOD level. The DO and BOD are inversely related. If BOD level is high, then DO will be less and vice versa. The biological oxygen demand is the indicator of the organic pollution of water. It occurs due 
to the decomposition of the organic matter by bacteria under anaerobic conditions. The permissible limit of BOD in river water is $<3 \mathrm{mg} / \mathrm{l}$. The BOD level in stations 5 and 6 (Thiruvallom and Moonnattumukk) is high (Table 3). If the BOD level increases, the dissolved oxygen level decreases thereby preventing the aquatic organisms to grow. The highest level of BOD was in Thiruvallom station, with value of $11.5 \mathrm{mg} / \mathrm{l}$ in the post-monsoon season (Table 2). Free ammonia was not recorded in all the stations.

Fecal coliform bacteria may occur in surface water due to the direct overflow of domestic sewage or nonpoint sources of human and animal waste. Fecal coliform bacteria was detected in all the stations, but higher rate was noticed in three stations (Pallathukadavu, Thiruvallom, and Moonnattumukk) (Table 2). Among these stations, station 6 Moonnattumukk recorded the highest rate in all the seasons. The reason behind this may be the higher quantity of discharge of the sewage from the households to the river water. The presence of total coliform bacteria indicates that water is contaminated with feces or sewage. The 4, 5 and 6 numbered stations (Pallathukadavu, Thiruvallom and Moonnattumukk) (Table 2) showed higher amount of TC in the water samples. The TC value was $43100 \mathrm{cfu} / 100 \mathrm{ml}$ in Moonnattumukk station in pre-monsoon time was the highest value obtained in the whole period of analysis. In all the seasons, the rate of TC was comparatively very high in this station. Peppara dam was showing the lowest values. It is very clear that the reason behind the increase in the rate of TC in the river is entirely due to the direct discharge from the household as it is a very thick urban zone.

SAR is the sodium adsorption ratio, which indicates a possible sodium hazard. When the SAR value is $>26$, the water is categorised as sodic. The highest value was noticed in the monsoon season, with a value of 15.54 at Pallathukadavu station (Table 2).

From the analysis it is evident that the river was maximum polluted with anthropogenic pollutants. The anthropogenic control leads to major pollution in the water. No significant contributions from the natural sources of ionic pollution were noticed. All the sampling stations were located in the urban zone except the Peppara dam station. The Peppara dam is away from the Thiruvananthapuram city in the Karamana river basin, where all the water quality parameters were relatively better. The highly polluted zones are located in the downstream urbanized area. Due to the high-level anthropogenic stress, all the sewage waste materials from the above sources are mixed directly into the surface water. Efficient sewage systems are required in this area to address the present scenario.

\section{Conclusion}

The temperature value ranges of the study area were not showing much variation in its values. The highest temperature in the pre-monsoon (summer) and the lowest temperature value in the post-monsoon (winter) are pretty common. The standard permissible limit of the $\mathrm{pH}$ value is 6.5-8.5 for the river water and most of the areas come in that range. The stations near the coastal area like Thiruvallom, Moonnattumukk, and Pallathukadav showed slight acidic character in pre-monsoon and post-monsoon season, especially the Thiruvallom station. The conductivity also showed a slight variation in Moonnattumukk, which may be due to the saltwater intrusion during the season. The turbidity in the 
Moonnattumukk may be due to algal growth, and the algae are common in some of the regions in the basin during the pre-monsoon season. The DO value in the Thiruvallom and the Moonnattumukk region were low because of the high BOD level in those areas. The high BOD in those regions results in less growth of the aquatic organisms. Both Fecal coliform and the total coliform rate are very high in Pallathukadavu, Thiruvallom, Moonnattumukk. The area of study is densely urbanized, which results in strong environmental stress. The results obtained from the study revealed the localized mode of pollution that occurred in the river. An efficient urban water management practice is required to minimize the impact on the quality of water in an urbanized area of Thiruvananthapuram. The controlling measures are required to be implemented by the stakeholders for the monitoring of water resources. Such practice will not only preserve the natural areas but also improve the quality of water. Frequent water quality checks should be done to identify the water pollution and the source of pollution. Proper mechanisms must be in place in the urban zones to stop the direct dumping of wastes from households. A proper sewage system should be developed to avoid the direct discharge of sewage waste. The industrial waste should be treated separately to remove all the toxicants.

\section{Declarations}

Ethical approval: All ethical practices have been followed in relation to the development, data analysis, writing and publication of this research article.

Consent to participate: Consent to participate is 'Not applicable' for the manuscript.

Consent to Publish: None of the data used belongs to any person in any form.

Authors contribution: M A Mohammed-Aslam conceptualized the idea. Reshma S R helped in the manuscript writing and collected the necessary resources to carry out this research.

\section{Funding: Nil .}

Competing interests: The authors declare no competing interests.

Availability of data and materials: The dataset utilized/analyzed during the current study will be available from the corresponding author upon request in accordance with the norms of pollution control board.

\section{ACKNOWLEDGEMENT}

The authors are thankful to the Kerala State Pollution Control Board (KSPCB) for the free access of water quality data. They wish to thank Dr. Sheela A.M, Chief Engineer, Head office, KSPCB, Thiruvananthapuram, for her valuable help and support.

\section{References}


Amrutha Lekshmi G R , V S Landge, V S Sanjay Kumar. 2016. Activity based travel demand modeling of Thiruvananthapuram urban area. Transportation Research Procedia 17, pp:498 - 505.

Angel, S., Stephen C. Sheppard and Daniel L. Civco. 2005. The Dynamics of Global Urban Expansion. Department of Transport and Urban Development, Washington, DC: World Bank, 13p.

APHA. 1995, Standard Methods for Examination of Water and Wastewater. 19th Edn., American Public Health Association, Washington, DC.

Bhagat, R. B., and Soumya Mohanty. 2009. Emerging Pattern of Urbanization and the Contribution of Migration in Urban Growth in India. Asian Population Studies, Vol. 5. pp 5-20.

Brockerhoff M. 1999. Urban Growth in Developing Countries: a review of Projections and Predictions. Popul Dev Rev ;25(4):757-78.

Census of India. 2011. Press Release: Rural-Urban distribution of Population (Provisional). Retrieved July 15, 2012, from Press Information Bureau website, http://pibmumbai.gov.in/English/PDF/E2011_PR1143.PDF.

Chang, Heejun. 2005. Spatial and Temporal Variations of Water Quality in the Han River and Its Tributaries, Seoul, Korea, 1993-2002. Water, Air, and Soil Pollution 161, pp: 267-284.

Chaolin G U, Liya W U and lan Cook. 2012. Progress in research on Chinese urbanization. Frontiers of Architectural Research.Volume 1, Issue 2, pp: 101-149.

Charutha Reghunathan and R. Anilkumar. 2015. Population Growth and Land Use Change: An Evaluation Based on the Physiographic Divisions of Thiruvananthapuram District, Kerala using Remote Sensing and GIS. International Journal of Science and Research (IJSR) ISSN (Online), 4(6):2733-2736.

Davis, K., 1965. The Urbanization of the Human Population, Scientific American, 213(3), pp. 41-55.

Franco S., Venkata Ravibabu Mandla, K. Ram Mohan Rao., 2016. Urbanization, energy consumption and emissions in the Indian context A review. Renewable and Sustainable Energy Reviews Volume 71, pp: 898907.

Herold M, Noah C, Goldstein Keith and C.Clarke. 2003. The spatiotemporal form of urban growth: measurement, analysis and modelling. Remote Sensing of Environment. Volume 86, Issue 3, pp: 286302.

Jaysawal, D. and Saha, S.,2014. Urbanization in India: An impact assessment. International Journal of Applied Sociology, 4(2), pp.60-65.

Krishnakumar, A., 1998. Hydro geochemistry of Vellayani, fresh water lake with special reference to drinking water quality. M.Phil. Thesis, University of Kerala, India. 
Kumar Jitendra and Kumar Sandeep. 2012. "Monitoring urban expansion and land use/land cover changes in Rohtak City using Remote Sensing and GIS technique”, International Journal of Advances in Remote Sensing and GIS, Vol. 1(2), pp:49-60.

Lalitha M and Mohammed-Aslam M.A. 2018. Geospatial analysis of groundwater quality around madayi clay mine area, kannur, kerala, india, Eco chronicle, 13(3): 97 - 106.

Maurya, S. D. 2017. Urban Geography. Journal of Macromolecular Science, Part A Pure and Applied Chemistry. Volume 55, issue 1, pp:1-10.

Misra RP. (1972) "Role of growth foci in regional development in urban system and rural development", Prasaranga Publications, Mysore.

Mohammed-Aslam, M. A., Rokhmatuloh, R. T., Salem, Z. E., \& Javzandulam, T. 2006. Linear Mixture Model applied to the land-cover classification in an alluvial plain using Landsat TM data. Journal of Environmental Informatics, 7(2), 95-101.

Mohammed-Aslam, M. A., Kondoh, A., P. Rafeekh Mohamed, \& Manoharan, A. N. 2010.

Evaluatinggroundwater potential of a hard-rock aquifer using remote sensing and geophysics. Journal of SpatialHydrology, 10(2).

Mohammed-Aslam MA, Lalitha M and Mahalingam B. 2020. The environmental implications of land use and land cover changes around a mined area at madayipara in kannur district, kerala state, india, Journal of Global Resources,6(01):1-7

Mohammed-Aslam, M.A., Rizvi, S.S. 2020. Hydrogeochemical characterisation and appraisal of groundwater suitability for domestic and irrigational purposes in a semi-arid region, Karnataka state, India. Appl Water Sci 10, 237

Mosammam, Hassan Mohammadian, Nia, JamilehTavakoli, Khani,Hadi, Teymouri, Asghar\&Kazemi, Mohammad. 2016. Monitoring landuse change and measuring urban sprawl based on its spatial forms: the case of Qom city. The Egyptian Journal of Remote Sensing and Space Science, Egypt ol 20, Issue 1, pp 103-116.

Rizvi, S.S., and Mohammed-Aslam, M.A. 2019. Microbiological quality of drinking water in Amarja reservoir catchment, Aland taluk, Karnataka, India. Current Science., 117(1), 114-121

Sadashivam T. and Shahla Tabassu. 2016. Trends of Urbanization in India: Issues and Challenges in the 21st Century. International Journal of Information Research and Review Vol. 03, Issue, 05, pp. $2375-2384$.

Satapathy, B.K. 2014. Safe drinking water in slums: from water coverage to water quality. Economic and Political Weekly, 49(4): pp:50-55. 
Smailes, A. E. 1975. The Definition and Measurement of Urbanisation. Essays of World Urbanisation, London. Pp: 690-710.

1. Satapathy, B K (2014): "Safe Dri nking Water in Slu ms:

2. From Water Coverage to Water Quality," Econom-

3. ic \& Polit ical Weekly, Vol 49, No 4, pp 50- 55

4. Satapathy, B K (2014): “Safe Dri nking Water in Slu ms:

5. From Water Coverage to Water Quality," Econom-

6. ic \& Polit ical Weekly, Vol 49, No 4, pp 50- 55

7. Satapathy, B K (2014): “Safe Dri nking Water in Slu ms:

8. From Water Coverage to Water Quality," Econom-

9. ic \& Polit ical Weekly, Vol 49, No 4, pp 50- 55.

Sreeja R. 2017. Evolution of Karamana River Basin and Its Implications on Hydrogeology: A Geomatics Approach Using Morphometric Analysis,Final technical reprt,Mahatma Ghandi University,Kottyaam (Project Report of KCSTE Back to Lab programme) pp 1-179.

Srikumar Chattopadhyay, K N Harilal, 2017. Emerging Challenges of Urban Water Governance Case of Thiruvananthapuram City, India. RULSG Occasional Paper2017:1, Centre for Development Studies, Thiruvananthapuram, 30p.

Sudhakar M. Rao and P. Mamatha.2004. Water quality in sustainable water management. Special Section: Application of S \&T to Rural Areas. Vol. 87, issue 7 pp. 942-947.

Sujitha P.C, Mitra Dev D, Sowmya P.K, Mini Priya R. 2012. Physico-chemical parameters of Karamana river water in Trivandrum district, Kerala, India. International Journal of Environmental Sciences Volume 2, No $3, \mathrm{pp} 0976-4402$.

Steven.C. Chapra. 2008. Surface Water Quality Modelling. Waveland publisher. Long Grove, U S. pp:232240 .

Whitney, R., 1990. Data on Ground-Water Quality in the Carson River Basin, Western Nevada and Eastern California, 1987-90. U.S. Geological Survey. Open File Report 94-39, 139p.

\section{Figures}



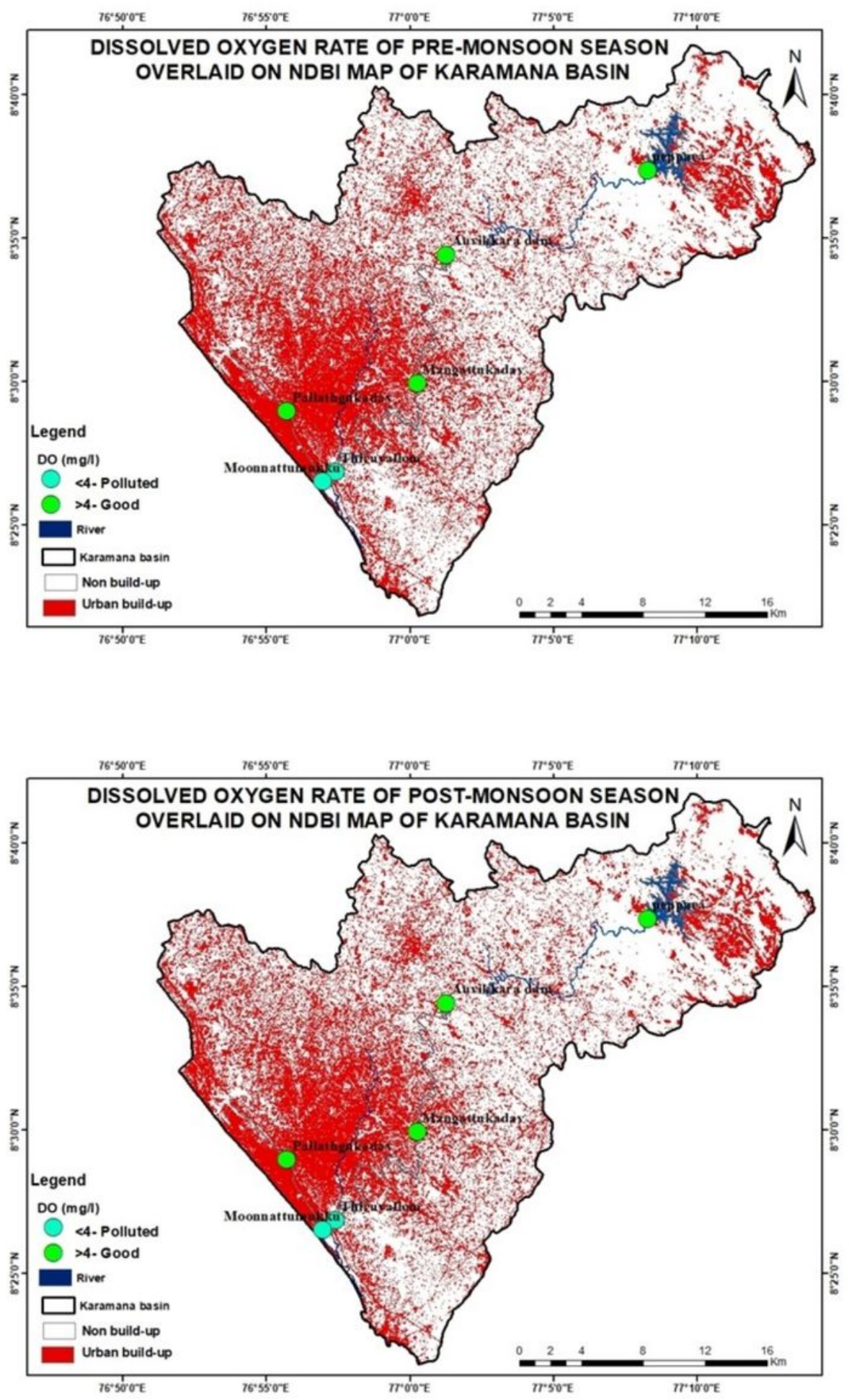

Figure 1

Dissolved oxygen of pre-monsoon and post-monsoon of Karamana basin 

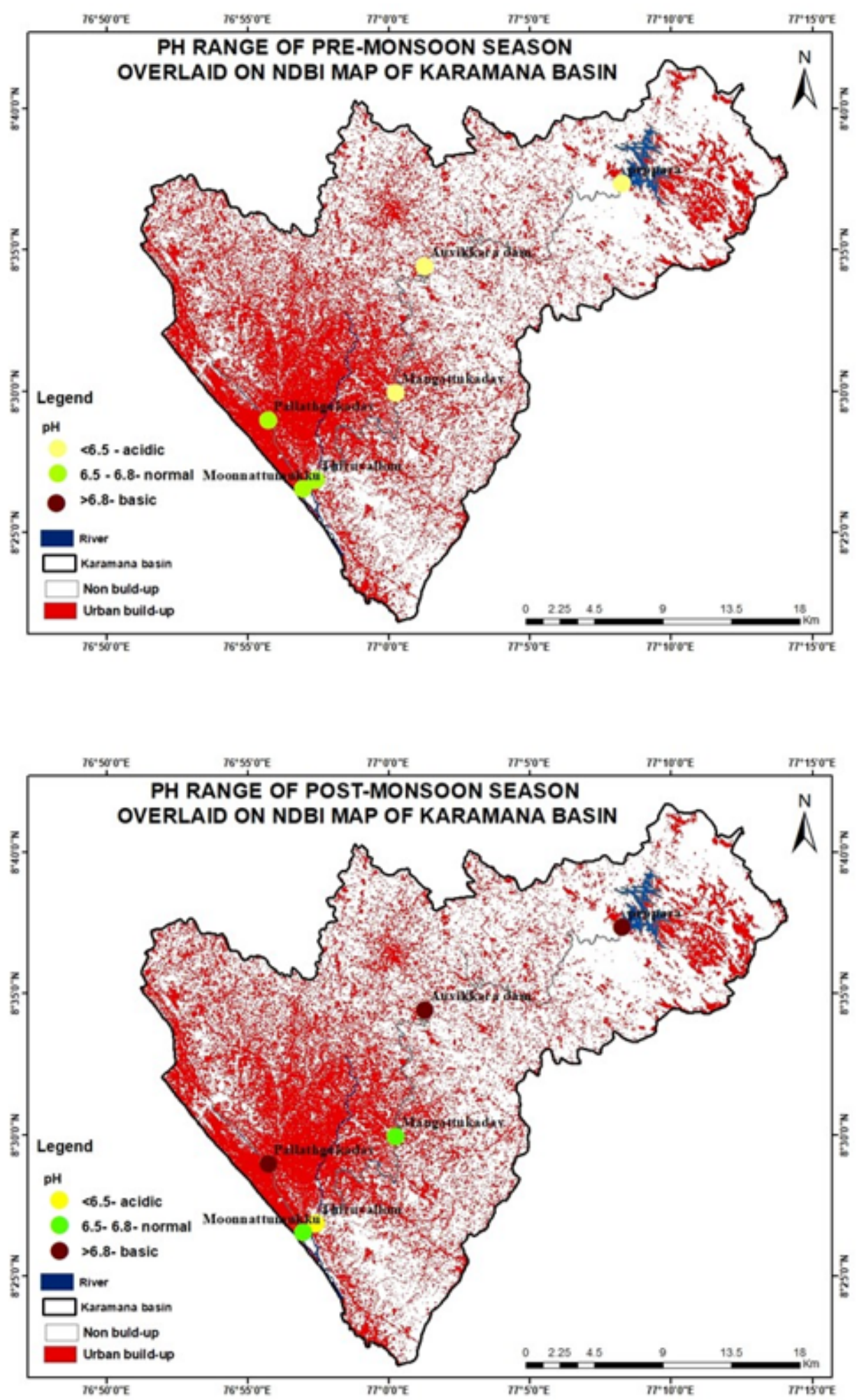

Figure 2

$\mathrm{pH}$ of pre-monsoon and post-monsoon of Karamana basin 

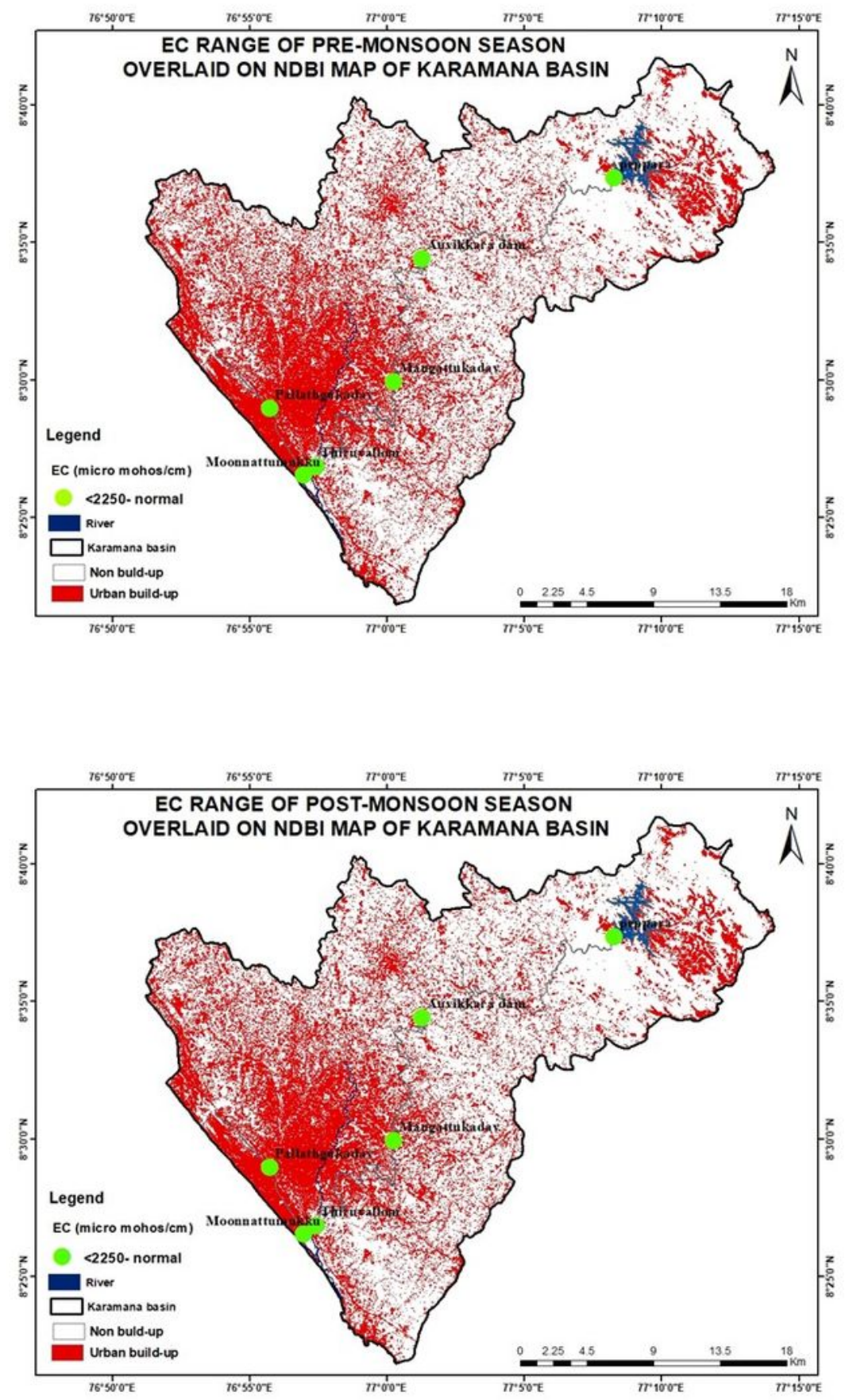

Figure 3

Electric conductivity (applicable for Class E type of water) of pre-monsoon and post-monsoon of Karamana basin 


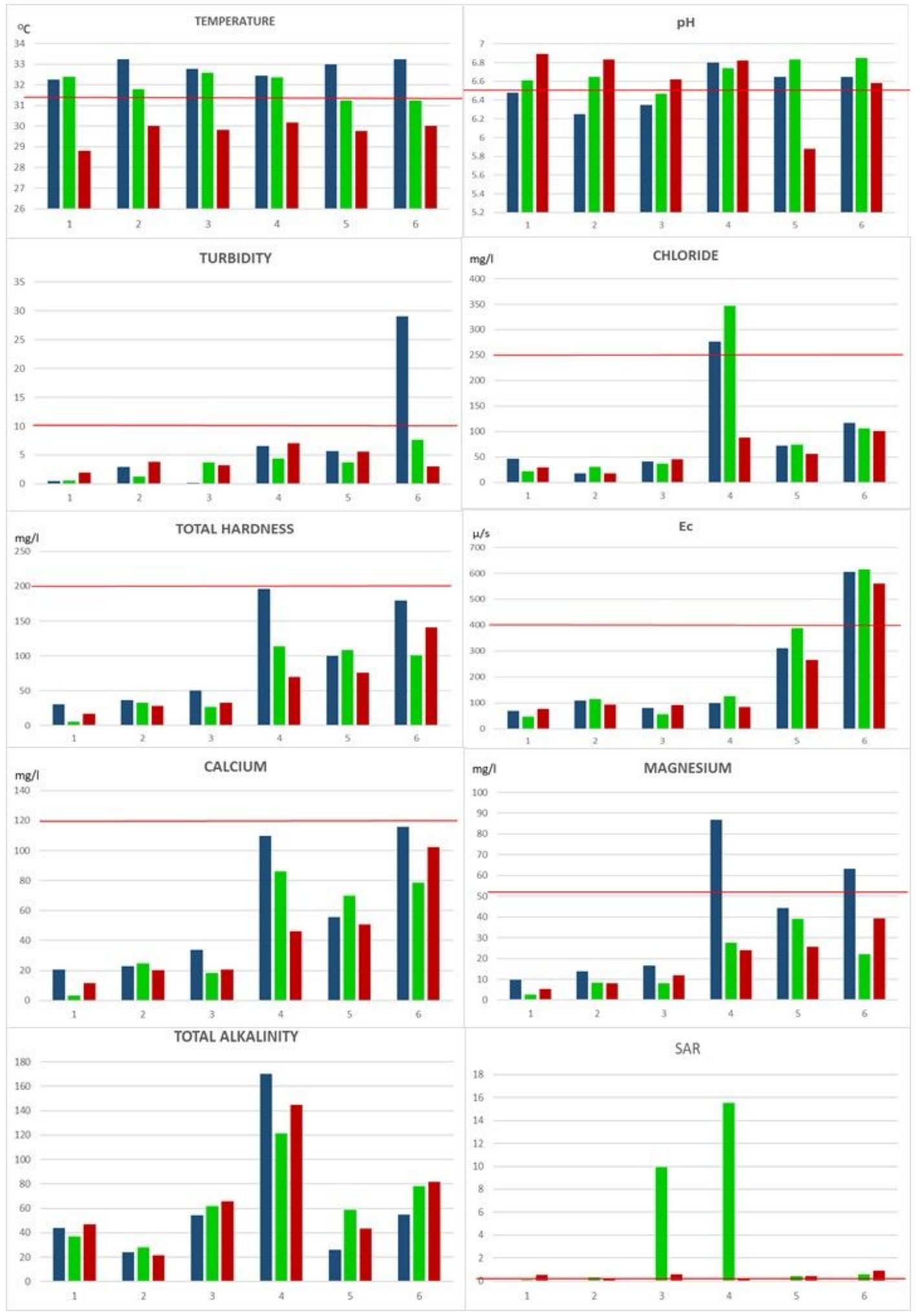

Figure 4

water quality parameters of pre-monsoon (blue), monsoon (green), and post-monsoon (red) 